Original Research Paper

\title{
The Biological Parameters as an Indicators of Water Quality for a Tourism Area Spot in Jurang Sate Primary Canal Central of Lombok, Indonesia
}

\author{
Baiq Dini Najia Dzurrahmi ${ }^{1}$, Agil Al Idrus ${ }^{1}$, Lalu Japa ${ }^{1^{*}}$ \\ ${ }^{1}$ Program Studi Pendidikan Biologi, FKIP Universitas Mataram, Indonesia
}

\begin{abstract}
Article History
Received : August $15^{\text {th }}, 2021$

Revised : August $30^{\text {th }}, 2021$

Accepted : September $15^{\text {th }}, 2021$

Published : September $25^{\text {th }}, 2021$

*Corresponding Author:

Lalu Japa,

Program Studi Pendidikan

Biologi, FKIP Universitas

Mataram, Indonesia

Email: 1japa@unram.ac.id
\end{abstract}

\begin{abstract}
Jurang Sate primary canal is one of the the main irrigation canal in central Lombok which supplies water from the main network, namely Jangkok, Sesaot, and Keru Feeder weir to several secondary canal and to irrigated tertiary plots. The local community use the Jurang Sate Primary canal in a variety of daily activities, and nowadays it is used as a means of water tourism. The purpose of this study was to determine the water quality for ectourism area of the Jurang Sate primary canal based on biological parameters, namely the total Coliform bacteria, and the diversity of phytoplankton community. Measurement of coliform bacteria parameters and phytoplankton diversity was carried out ex-situ. The results showed that the total Coliform bacteria count in each sample calculated with MPN index was in the range of 170-110000 MPN/100 ml. The phytoplankton identified in this study were 24 species, 15 orders, and 6 classes. The phytoplankton species diversity index was in medium category. The conclusion of this research were (1). The water of the primary channel of Jurang Sate was categorized in moderately polluted. (2). The water of the Jurang Sate primary canal is not ideal for water ecotourism activity.
\end{abstract}

Keywords: Biological Parameters, Jurang Sate, Phytoplankton

Diversity, Total Coliform Bacteria, Water Quality

\section{Pendahuluan}

Air memiliki banyak fungsi dalam kehidupan sehari-hari. Secara umum air digunakan oleh organisme untuk beberapa reaksi kimia dalam proses metabolisme termasuk menjadi media transportasi nutrisi dan hasil metabolisme. Bagi manusia, air memiliki peranan yang sangat besar bukan saja untuk penemuhan kebutuhan biologisnya, tetapi juga untuk kelangsungan berbagai bentuk aktivitas sehari-hari sperti mencuci, memasak, keperluan indusri, wisata, dan lain-lain (Wiryono, 2013). Tidak dapat dipungkiri bahwa penurunan kualitas air dewasa ini merupakan dampak dari aktivitas manusia yang mengeksploitasi lingkungan secara berlebihan. Pola kehidupan masyarakat yang kurang memperhatikan aspek lingkungan seperti membuang sampah dan limbah berbahaya lainnya secara semabarangan, telah memberikan dampak negatif baik secara langsung maupun tidak langsung terhadap lingkungan alami termasuk sumber air (Sulistyorini, et al.., 2016). Akibat buangan limbah ke sumber air menyebabkan terganggunya ekosistem sungai. Air menjadi berubah warna, berbau, pemandangan terganggu dan menimbulkan masalah kesehatan manusia (Mardhia dan Abdullah, 2018). Sulistyorini, et al. (2016) menyatakan bahwa, tingkat kualitas air yang dibutuhkan untuk setiap kegiatan tertentu memiliki baku mutu yang berbeda. Oleh karena itu, harus dilakukan pengujian untuk mengetahui kesesuaian kualitas dengan peruntukannya. Analisis kualitas air dapat dilakukan dengan menggunakan parameter fisika, kimia dan biologi.

Parameter biologi bagi kualitas air yang normal dapat ditentukan berdasarkan kriteria mutu air dari PP No 82 tahun 2001, tentang Pengelolaan Kualitas Air dan Pengendalian Pencemaran Air. Parameter biologi yang dapat digunakan untuk menentukan kualitas air dapat berupa total bakteri Coliform. Pratiwi et al. (2019) menyatakan bahwa kualitas air sungai dapat diketahui dengan indicator mikrobiologi yang dapat berupa virus maupun bakteri. Bakteri yang dapat dijadikan indicator perairan adalah baketri coliform. Parameter biologi lainnya yang juga banyak digunakan adalah fitoplankton. 
Fitoplankton sebagai salah satu bioindikator penting dalam menentukan kualitas atau pencemaran suatu perairan (Wijaya dan Hariyati, 2011; Lestari, 2015; Sugianti et al., 2015; Saragih dan Erizka, 2018). Sugianti et al., 2015 menegaskan, menyatakan bioindikator fitoplankton lebih mudah digunakan sebagai petunjuk untuk memantau terjadinya pencemaran suatu perairan dibandingkan dengan indikator kimia fisika karena sifatnya yang berkelanjutan. Penggunaan fitoplankton sebagai bioindikator pencemaran air digambarkan dari komposisi dan kelimpahannya (Wijaya dan Hariyati, 2011). Fitoplankton dapat dijadikan sebagai bioindikator perairan karena sifatnya yang lebih toleran terhadap bahan pencemar. Perubahan kualitas perairan dapat menyebabkan ketidakseimbangan suatu ekosistem. Selanjutnya fitoplankton akan mempengaruhi kehidupan di perairan karena peranan penting sebagai produsen utama bagi berbagai organisme dalam ekosistem perairan (Nirmalasari, 2018).

Nilai keanekaragaman spesies fitoplankton dapat mempengaruhi kualitas air. Menurut Agustina dan Mpoke (2016) Keragaman jenis merupakan parameter yang digunakan dalam mengetahui suatu komunitas. Parameter ini mencirikan kekayaan jenis dan keseimbangan dalam suatu komunitas. Indeks keanekargaman spesies tergolong menjadi tiga kategori untuk mengetahui kualitas air suatu perairan yaitu: $H^{\prime}<1$ (keanekaragaman rendah, komunitas biota tidak stabil dan kualitas air tercemar berat); $1 \leq \mathrm{H}^{\prime} \leq 3$ (keanekaragaman sedang, stabilitas komunitas biota sedang dan kualitas air tercemar sedang); $\mathrm{H}^{\prime}>3$ (keanekaragaman tinggi, stabilitas komunitas biota dalam kondisi prima (stabil) dan kualitas air bersih).

Saluran primer Jurang Satemerupakan salah satu bagian dari daerah irigasi Jurang sate (DI. Jurang Sate) yang menyuplai air dari jaringan utama yaitu bendung Jangkok Feeder, bendung Sesaot Feeder, dan bendung Keru Feeder menuju beberapa saluran sekunder dan ke petak-petak tersier yang diairi.Saluran primer Jurang Sate telah dibangun pada tahun 1987 sepanjang $17 \mathrm{Km}$ untuk mengairi DI. Jurang Sate hulu dengan luas 4.095 Ha dan DI. Jurang Sate hilir seluas 6.383 Ha (Kementrian Pekerjaan Umum dan Perumahan Rakyat, 2019). Saluran primer Jurang Sate mengalir kelewati wilayah tiga kecamatan yaitu Kecamatan Pringgarata, Jonggat, dan Praya. Bagian hulu saluran Jurang Sate terletak di Kecamatan Pringgarata dan bagian hilirnya terletak di Kecamatan Praya.Tujuan dari penelitian ini adalah untuk mengetahui kualitas perairan untuk ekowisata di saluran primer Jurang Sate berdasarkan parameter biologi yaitu total bakteri Coliform, dan keanekaragaman fitoplankton.

Penelitian tentang paremeter biologi sebagai indicator suatu perairan diantaranya pernah dilaporkan oleh Anisafitri et al. (2020) terkait analisis bakteri coliform di sungai Unus Lombok. Keanekaragman fitoplankton pada bendungan Pandanduri, Lombok Timur yang dilaporkan oleh Zohri, et al. (2020). Keragaman Chlorophyta di perairan bendungan Pandanduri Lombok Timur dialporkan oleh Zikriah et al. (2020). Akan tetapi informasi terkait parameter biologi sebagai indicator kualitas air pada saluran primer Jurang Sate sejauh ini belum dilaporkan. Oleh karena itu dipandang perlu penelitian terkait "Parameter Biologi sebagai Indikator Kualitas Air untuk Ekowisata pada Saluran Primer Jurang Sate, Lombok Tengah".

\section{Bahan dan Metode}

\section{Waktu dan Tempat}

Penelitian ini dilaksanakan dari bulan Agustus 2020-Juli 2021. Sampel air diambil pada Saluran Primer Jurang Sate, Kabupaten Lombok Tengah. Pengukuran total bakteri Coliform dilakukan di Balai Laboratorium Kesehatan dan Kalibrasi Nusa Tenggara Barat. Adapun pengamatan dan identifikasi fitoplankton dilakukan di Laboratorium Biologi FKIP Univesitas Mataram.

\section{Metode Pengambilan Sampel}

Titik pengambilan sampel ditentukan menggunakan teknik purposive sampling. Siyoto dan Sodik (2015) menyatakan bahwa, purposive sampling merupakan suatu teknik penentuan sampel dengan pertimbangan tertentu atau seleksi khusus.

Tiga titik pengambilan sampel yang adalah: titik 1 pada daerah hulu saluran primer Jurang Sate; titik 2 pada badan aliran sungai yang berjarak 1 kilo dari lokasi 1 (satu) yang merupakan kawasan padat penduduk; dan titik 3 pada lokasi 3 kilo meter dari daerah hulu Saluran Primer Jurang Sate. Posisi geografis titik pengambilan sampel ditentukan menggunakan GPS (Global Positioning System) seperti tercantum pada Tabel 1. Pola sebaran titik pengambilan sampel dapat disajikan pada Gambar 1. 


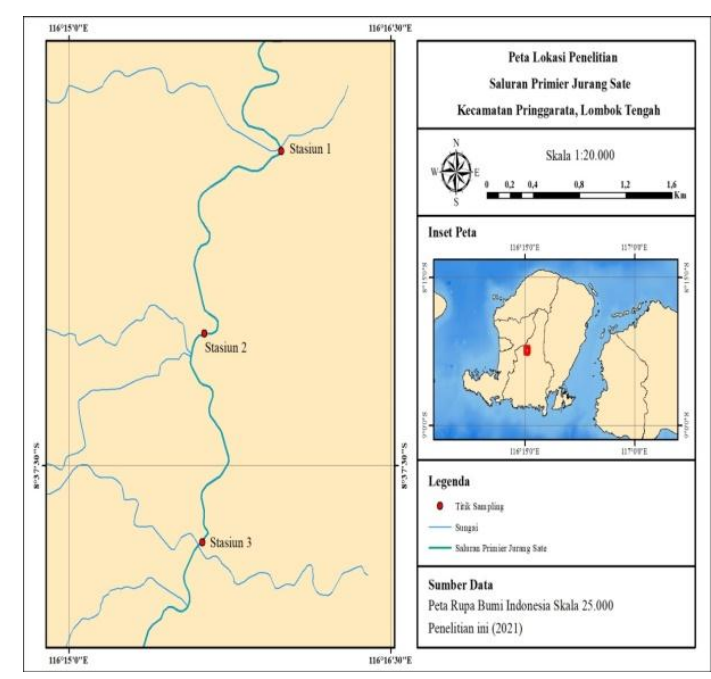

Gambar 1. Peta Titik Pengambilan Sampel pada Saluran Primer Jurang Sate, Kecamatan Pringgarata

Tabel 1. Koordinat Lokasi Titik Pengambilan Sampel

\begin{tabular}{llll}
\hline \multirow{2}{*}{ No. } & Titik & \multicolumn{2}{c}{ Posisi Geografis } \\
\cline { 3 - 4 } & Sampling & Latitude & Longitude \\
\hline 1. & Titik & S $8^{\circ} 36^{\prime} 24$, & E $116^{\circ}$ \\
& Sampling I & $82164^{\prime \prime}$ & $15^{\prime} 59$, \\
& & & $29236^{\prime \prime}$ \\
2. & Titik & S 8 $8^{\circ} 37^{\prime} 2$, & E $116^{\circ}$ \\
& Sampling & $66988^{\prime \prime}$ & $15^{\prime} 37$, \\
& II & & $80108^{\prime \prime}$ \\
3. & Titik & S 8 8 37'45, & E 116 \\
& Sampling & $93576^{\prime \prime}$ & $15^{\prime} 37$, \\
& III & & $25244^{\prime \prime}$ \\
\hline
\end{tabular}

\section{Prosedur Pengambilan Sampel}

Pengambilan sampel air untuk pemeriksaan bakteri Coliform dilakukan secara langsung menggunakan botol kaca gelap dan steril. Sampel air untuk pengamatan fitoplankton diambil menggunakan jaring plankton, mata jaring berukuran $20 \mu \mathrm{m}$. Sampel air sebanyak 50 $\mathrm{ml}$ diambil pada setiap titik pengambilan sampel yang merupakan pemakatan 100 liter dengan menggunakan jaring plankton. Sampel air untuk fitoplankon diawet dengan formalin pada konsentrasi pengawetan $4 \%$.

Sampel diamati di Laboratorium Biologi PMIPA FKIP UNRAM menggunakan mikroskop binokuler merk Olympus pada perbesaran 10x20, 10x40, dan 10x100. Identifikasi spesies fitoplankton berdasarkan karakteristik morfologi sel, dan koloni, dengan mengacu pada Cooper dan Dolan (2006), Sulastri (2014), Sahoo dan Seckbach (2015), dan Chepurnov, et.al. (2019).

\section{Analisis Data}

Total bakteri Coliform yang diperoleh pada setiap titik pengambilan sampel dianalisis berdasarkan pada kriteria mutu air dari PP no 82 tahun 2001, tentang pengelolaan kualitas air dan pengendalian pencemaran air (Tabel 2).

Tabel 2. Kriteria Mutu Air Berdasarkan Kelas

\begin{tabular}{|cccccc|}
\hline Pare & Satu & \multicolumn{4}{c|}{ Kelas } \\
meter & an & I & II & III & IV \\
Bakte & Jml/ & 1000 & 5000 & 10000 & 10000 \\
ri & 100 & & & & \\
Colif & ml & & & & \\
orm & & & & & \\
\hline
\end{tabular}

Indeks keanekaragaman spesies fitopalnkton dihitung menggunakan rumus dari Shannon Wienner. Kriteria nilai indeks keanekaragaman spesies fitpolankton sebagai indikator tingkat pencemaran air mengacu pada Wardhana (2006), seperti tercantum pada Tabel 3.

Tabel 3. Klasfikasi Tingkat Pencemaran berdasarkan Indeks Keanekaragaman Shannon-Wienner (Wardhana, 2006)

\begin{tabular}{lll}
\hline Indeks Keanekaragaman $\left(\mathrm{H}^{\prime}\right)$ & Tingkat Keanekaragaman & Tingkat Pencemaran \\
\hline $\mathrm{H}^{\prime}<1$ & Rendah & Tercemar berat \\
$1,1-2,9$ & Sedang & Tercemar sedang \\
$\mathrm{H}^{\prime}>3$ & Tinggi & Tercemar ringan \\
\hline
\end{tabular}

\section{Hasil dan Pembahasan}

\section{Total Bakteri Coliform}

Paremeter biologi yang digunakan untuk menganalisis kualitas air pada Saluran Primer Jurang Sate adalah total bakteri Coliform dan komunitas fitoplankton. Hasil pemeriksaan total bakteri Coliform pada setiap sampel yang terhitung dengan indeks MPN adalah berkisar antara $170-110000 \mathrm{MPN} / 100 \mathrm{ml}$. Nilai ideks MPN tertingi terdapat pada lokasi titik sampel 3 yaitu $110000 \mathrm{MPN} / 100 \mathrm{ml}$, sedangkan indeks 
terendah pada lokasi titik sampel 1 yaitu 170 (Tabel 4).

Tabel 4. Hasil Analisis Rata-Rata Total Bakteri Coliform Pada 3 Titik Sampel Air Saluran Primer Jurang Sate

\begin{tabular}{ccc}
\hline $\begin{array}{c}\text { Lokasi } \\
\text { Titik } \\
\text { Sampel }\end{array}$ & $\begin{array}{c}\text { Kadar } \\
\text { Maksimal } \\
(\text { MPN/100 ml) }\end{array}$ & $\begin{array}{c}\text { Total Bakteri } \\
\text { Coliform } \\
(\text { MPN/100 ml })\end{array}$ \\
\hline 1 & 10000 & 170 \\
2 & 10000 & 21000 \\
3 & 10000 & 110000 \\
\hline \multicolumn{2}{c}{ Rata-rata } & 43.723 \\
\hline
\end{tabular}

Hasil pemeriksaan total bakteri Coliform pada sampel yang terhitung dengan indeks MPN memiliki rata - rata sebesar $43.723 \mathrm{MPN} / 100 \mathrm{ml}$. Nilai ini melebihi ambang batas maksimum nilai total bakteri Coliform menurut standar baku mutu air yang ditetapkan oleh Peraturan Pemerintah No. 82 tahun 2001 yaitu dengan nilai maksimum 10000 MPN/100 ml. Rata-rata Coliform yang diperoleh pada panelitian ini, lebih rendah dari total bakteri Coliform pada sungai Jangkuk dilaporkan oleh Faqih dan Fitasari (2012), tetapi lebih tinggi dibanding total bakteri Coliform pada Sungai Unus Lombok yang dilaporkan oleh Anisafitri, at al. (2020).
Total bakteri Coliform tertinggi yakni pada titik ketiga yang terletak pada daerah padat pemukiman penduduk dan merupakan titik pengambilan sampel yang memiliki jarak paling jauh dari daerah hulu. Berdasarkan hasil observasi kebiasaan penduduk setempat membuang feses dan urin secara langsung, mandi dan mencuci pakaian secara lngsung di aliran sungai, dan pembuangan limbah rumah tangga dapat menjadi faktor tingginya kandungan total Coliform pada titik ketiga pengambilan sampel.

\section{Kenaekaragaman Fitoplankton}

Total 24 spesies fitoplankton yang berhasil diidentifikasi dalam penelitian ini, meliputi 15 ordo dan 6 kelas (Tabel 5). Jumlah spesies tertinggi terdapat pada titik satu yaitu 13 spesies dan jumlah spesies terendah adalah pada titik tiga yaitu 4 spesies. Jumlah spesies fitoplankton di perairan saluran primer Jurang Sate lebih rendah dibanding beberapa lokasi perairan lainnya di wilayah Nusa Tenggara Barat seperti: bendungan Pandanduri didapatkan 31 spesies (Zohri, et al., 2020), muara sungai Pelangan sebanyak 50 spesies (Astuti et al., 2017). Tetapi kemudian lebih banyak dibanding jumlah spesies fitoplakton di perairan Taman Nasional Gunung Rinjani (20 spesies) seperti yang dilaporkan oleh (Budiarsih, 2019).

Nilai indeks keanekaragaman spesies fitoplankton pada setiap titik sampel yaitu : masing-masing 0,$86 ; 2.20$; dan 0,89 pada titik pertama, kedua, dan ketiga (Gambar 2).

Tabel 5. Daftar Kelas, Ordo, dan Spesies Fitoplankton pada Saluran Primer Jurang Sate, Lombok Tengah

\begin{tabular}{|c|c|c|c|c|c|}
\hline \multirow[t]{2}{*}{ Kelas } & \multirow[t]{2}{*}{ Ordo } & \multirow[t]{2}{*}{ Spesies } & \multicolumn{3}{|c|}{ Titik } \\
\hline & & & 1 & 2 & 3 \\
\hline \multirow[t]{5}{*}{ Cyanophyceae } & Chroococcales & Aphanocapsa & $*$ & & \\
\hline & & Gleocapsa alpicola & $*$ & & \\
\hline & Nostocales & Oscillatoria sp. & $*$ & $*$ & $*$ \\
\hline & & Oscillatoria tenius & & $*$ & \\
\hline & Chamaesiphonales & Chamaesiphon sp. & $*$ & & \\
\hline \multirow[t]{3}{*}{ Chlorophycea } & Chlamydomonadale & Haematococus & $*$ & & $*$ \\
\hline & $\mathrm{s}$ & & & & \\
\hline & Chlorococcales & Oocistys & $*$ & & \\
\hline \multirow[t]{2}{*}{ Bacillariophyceae } & Achnanthales & Achnanthes sp. & $*$ & & \\
\hline & Naviculales & Navicula sp. & $*$ & & \\
\hline
\end{tabular}




\begin{tabular}{|c|c|c|c|c|c|}
\hline & Biddulphiales & Leptocilyndricus sp. & $*$ & & \\
\hline & & Thalassiosira sp. & $*$ & & \\
\hline & & Thalassiosira weisflogii & & $*$ & $*$ \\
\hline & & Biddulphia aurita & & $*$ & \\
\hline & Pennales & Amphora sp. & & $*$ & \\
\hline & & Bacillaria paradoksa & & $*$ & \\
\hline & & Striatella unipunctataa & & $*$ & \\
\hline & & Licmophora & & $*$ & \\
\hline & Centralles & Paralia sulcata & & & $*$ \\
\hline Dinophyceae & Gymnodiniales & Polykrikos schwrtzii & & $*$ & \\
\hline & & Polykrikos hartamany & $*$ & & \\
\hline & Gonyaulacales & Gonyaulax sp & $*$ & & \\
\hline Euglenaceae, & Euglenophyceae & Euglena sp & & $*$ & \\
\hline Coscinodiscophyceae & Hemiaulales & Hemialus sinensis & $*$ & & \\
\hline
\end{tabular}

Ket. $*$ = ditemukan

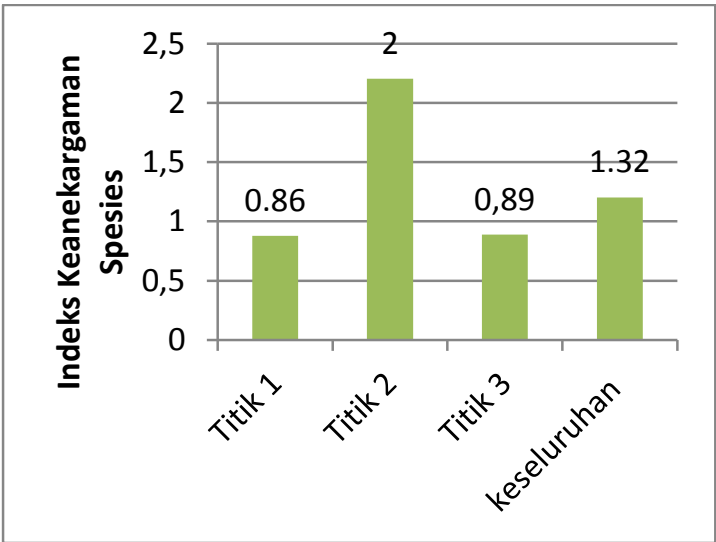

Gambar 2. Nilai Indeks Keanekaragaman Spesies Fitoplankton Pada 3 Titik Sampel Air Saluran Primer Jurang Sate

Nilai indeks keanekaragaman spesies fitoplankton perairan saluran irigasi Jurang Sate adalah 1,32 (kategori sedang). Nilai ini lebih rendah dibanding hasil penelitian yang dilakukan oleh Mayagitha et al. (2014) dan Astuti et al. (2020). Wardhana (2006) menegaskan, nilai indeks keanekaragaman 1,1-2,9 termasuk kategori keanekaragaman sedang. Keanekaragaman tertinggi terdapat pada titik II yaitu dengan nilai 2,20, hal ini bisa jadi disebabkan karena lokasi titik II memiliki tingkat arus yang lebih rendah dibanding lokasi titik I dan III. Salah satu yang menyebabkan rendahnya indeks keanekaragaman adalah lokasi pengambilan sampel yang memiliki arus yang tinggi menyebabkan jumlah individu dan spesies fitoplankton lebih sedikit (Mardani et al., 2016 dalam Zohri, et al., 2020).

Menurut Astuti et al. (2017) tinggi rendahnya indeks keanekaragaman spesies fitoplaknton pada suatu perairan dipengaruhi oleh jumlah jenis mikroalga yang ditemukan di masing-masing titik tersebut.Semakin tinggi jumlah spesies yang ditemukan, maka indeks keanekaragaman jenisnya juga semakin tinggi. Hasil penelitian ini menunjukkan bahwa jumlah spesies yang paling banyak dengan jumlah individu yang merata terdapat pada titik II, sehinnga didapatkan nilai indeks keanekaragaman tertinggi pada titik II.

Faktor fisika dan kimia perairan seperti suhu, $\mathrm{pH}$, oksigen terlarut, nitrat dan fospat juga sangat berpengaruh terhadap keanekaragaman spesies fitoplankton. Suhu perairan saluran primer Jurang Sate berkisar antara $27-28^{\circ} \mathrm{C}$, masih termasuk dalam temperatur optimal untuk pertumbuhan fitoplankton. Menurut Raymont (1981) dalam Mayagita et al. (2014), secara umum kisaran suhu yang optimal bagi perkembangan plankton di daerah tropis adalah $25^{\circ} \mathrm{C}-32^{\circ} \mathrm{C}$. Adapun nilai $\mathrm{pH}$ yang berkisar antar 6-7 juga termasuk dalam $\mathrm{pH}$ optimal untuk pertumbuhan fitoplankton. Pelczar (2010) dalam Harmoko et al. (2017) menyatakan, bahwa derajat keasaman optimum untuk pertumbuhan dan perkembangan normal fitoplankton adalah 411. 
Kandungan fosfat juga masih dapat dikatakan memilki kadar yang optimal untuk pertumbuhan fitoplankton yaitu berkisar antara <0,046-0,052. Yuliana et al. (2012) melaporkan, bahwa perairan Teluk Jakarta memiliki kandungan fosfat $0,0114-0,102 \mathrm{mg} / \mathrm{L}$ termasuk dalam kadar yang optimal untuk pertumbuhan fitoplankton sehingga didapatkan nilai indeks keanekaragaman sedang $\left(\mathrm{H}^{\prime}=1,1-2,9\right)$.

Kandungan nitrat perairan juga dapat dikatakan optimal untuk pertumbuhan fitoplankton pada air tawar yaitu berkisar antara 0,956-1,07 mg/L. Sebagaimana hasil penelitian pada danau Toba yang dilaporkan oleh Barus (2004), bahwa perairan memiliki kandungan nitrat yang berkisar antara 0,234-0,611 dengan indeks keanekaragaman yang sedang yaitu nilai indeks $\mathrm{H}^{\prime}=1,2-1,5$.

Nilai indeks keanekaragaman spesies fitoplankton perairan saluran primer Jurang Sate sebesar 1,32 menunjukkan tingkat keanekargaman spesies kategori sedang. Menurut Wardhana (2006), Nilai indeks keanekaragaman spesies $\left(\mathrm{H}^{\prime}\right)=<1,1$ termasuk kategori rendah, adapun 1,1- 2,9 termasuk kategori keanekaragaman sedang, dan > 2,9 termasuk kategori tinggi. Tingkat keanekargaman spesies fitoplankton yang rendah menunjukkan, bahwa peraiaran mengalami pencemaran berat, sedangkan Tingkat keanekaragaman spesies fitoplankton yang sedang menunjukkan pencemaran sedang, dan tingkat keanekaragaman spesies fitoplankton yang tinggi menunjukkan pencemaran yang rendah. Basmi (1999) menyatakan, bahwa nilai keanekaragaman spesies fitoplankton kurang dari 1 berarti keanekaragaman rendah, produktivitas rendah, tekanan ekologis berat, ekosistem tidak stabil, komunitas biota tidak stabil atau perairan dalam kondisi tercemar. Haninuna, et al. (2015) menyatakan, bahwa ada kaitan erat antara nilai keanekaragaman spesies fitoplankton dan beberapa macam jenis pollutan penyebab pencemaran air. Pernyataan tersebut membuktikan bahwa, nilai keanekaragaman spesies fitoplankton dapat menentukan tingkat mutu kualitas air. Oleh karena itu, berdasarkan indeks keanekaragaman spesies fitoplankton maka dapat dikatakan, bahwa kualitass air pada Saluran Primer Jurang Sate termasuk kategori tercemar tercemar sedang.

\section{Kesimpulan}

Indeks keanekaragaman spesies fitoplankton perairan saluran primer Jurang Sate tergolong termasuk kategori sedang dan total bakteri Coliform sebesar 43.723,4 MPN/100 ml. Perairan saluran Jurang Sate dalam kondisi pencemaran sedang dan tidak layak diperuntukan sebagai sarana wisata air.

\section{Ucapan Terima Kasih}

Terimakasih disampaikan kepada FKIP, Universitas Mataram, khususnya Pengelola Laboratorium Biologi PMIPA yang telah menyediakan fasilitas dalam pelaksanaan pengamatan sampel. Selanjutnya, terimasih juga ditujukan kepada pihak BLKPK yang telah membantu proses análisis bakteri coliform dalam penelitian ini.

\section{Refferences}

Agustina \& Mpoke (2016). Keanekaragaman Fitoplankton sebagai Indikator Tingkat Pencemaran Perairan Teluk Lalong Kota Luwuk. Jurnal Balik Diwa, 7(2), 1-6.

Anisafitri, Khairuddin \& Rasmi D.A .C. (2020). Analysis of Coliform Bacteria As a WaterPollution Indicator in Unus River Lombok. Jurnal Pijar MIPA. 15(3):266272.

Astuti W, Astuti S, Suripto \& Japa L. (2017). Komunitas Mikroalga di Perairan Sungai dan Muara Sungai Pelangan Kecamatan Sekotong Kabupaten Lombok Barat. Jurnal Biologi Tropis. 17(1):76-86.

Barus (2004). Faktor-Faktor Lingkungan Abiotik dan Keanekaragaman Plankton Sebagai Indikator Kualitas Perairan Danau Toba. Jurnal Manusia dan Lingkungan. XI (2):64-72.

Basmi, S. (1999). Ekologi Plankton I. Fakultas Pertanian IPB: Bogor

Budiarsih, T. (2019). Keanekaragaman Mikroalga Pada Sumber Air Panas Di Kawasan Taman Nasional Gunung Rinjani Sebagai Bahan Tambahan Praktikum Botani Tingkat Rendah.Hasil Riset tidak Dipublikasi sebagai Syarat Gelar Sarjana, Universitas Mataram, Mataram, Indonesia. 
Chepurnov, Steiguber \& Siegel (2019). Diatoms as Hatchery Feed on-Site Cultivation and Alternative. Hatcheryfeed. 6(3): 23-27.

Copper S., \& Dollan C. (2006). A Guide to Common Gulf of Maine Phytoplankton.Great Bay Coast Watch.

Faqih \& Fitasari (2020). Analisis Penyebab Beban Pencemaran Daerah Aliran Sungai (DAS) Jangkok Dari Aspek Fisika Dan Mikrobiologi E Jurnal Binawakarya. 14(6): 2739-2744.

Haninuna, Gimin \& Kaho (2015). Pemanfaatan Fitoplankton Sebagai Bioindikator Berbagai Jenis Polutan di Perairan Intertidal Kota Kupang.Jurnal Ilmu Lingkungan. 13(2): 72-85.

Harmoko, Lokaria \& Misra (2017). Eksplorasi Mikroalga Di Air Terjun Watervang Kota Lubuklinggau. 8(1): 75-81.

Kementrian Pekerjaan Umum dan Perumahan Rakyat. (2019). Profil Daerah Irigasi Jurang Sate. Diakses dari: https://sda.pu.go.id/balai/bwsnt1/post/44/ profil-daerah-irigasi-jurang-sate

Lestari (2015). Struktur Komunitas Fitoplankton Sebagai Bioindikator Perairan Di Bendungan Batu Jai Kabupaten Lombok Tengah. Skripsi. S1 Pendidikan Biologi, FKIP Universitas Mataram.

Mardhia \& Abdullah (2018). Studi Analisis Kualitas Air Sungai Brangji Sumbawa Besar. Jurnal Biologi Tropis. 18(2): 182189.

Mayagitha, Haeruddin \& Rudiyanti (2014). Status Kualitas Perairan Sungai Bremi Kabupaten Pekalongan Ditinjau dari Konsentrasi TSS, BOD5, COD dan Struktur Komunitas Fitoplankton. Diponegoro Journal of Maquares. 3(1):177-185.

Nirmalasari (2018). Analisis Kualitas Air Sungai Sebangau Pelabuhan Kereng Bengkiray berdasrkan Keanekaragaman dan Komposisi Fitoplankton. Jurnal Ilmu Alam dan Lingkungan. 9(17): 48-58.
Peraturan Pemerintah No 82 Tahun 2001.2001. Jakarta.

Pratiwi, Widyorini \& Rahman (2019). Analisis Kualitas Perairan berdasrkan Total Bakteri Coliform di Sungai Plumbon, Semarang.Journal of Maquares. 8(3): 211220.

Sahoo, D., \& Seckbach, J. (2015). The Algae World. New York: Springer Science Business Media Dordrecht.

Saragih \& Erizka (2018). Keanekaragaman Fitoplankton sebagai Indikator Kualitas air Danau Sipin di Kota Jambi. Jurnal Daur Lingkungan. 1(1):22-28.

Siyoto, S., \& Sodik, A. (2015) .Dasar Metodologi Penelitian. Yogyakarta: Literasi Media Publishing

Sulastri (2014). Fitoplankon Danau-Danau di Pulau Jawa. LIPI Press: Jakarta.

Sulistyorini, Edwin \& Arung (2016). Analisis Kualitas Air pada Sumber Mata Air di Kecamatan Karangan dan Kaliorang Kabupaten Kutai Timur.Jurnal Hutan Tropis. 4(1): 64-76.

Wardhana (2006). Dampak Pencemaran Lingkungan.Yogyakarta: Penerbit Andi.

Wiryono (2013). Pengantar Ilmu Lingkungan. Pertelon Media: Bengkulu.

Yuliana, Adiwilaga, Haris \& Pratiwi (2012). Hubungan Antara Kelimpahan Fitoplankton Dengan Parameter Fisik Dan Kimiawi Perairan Di Teluk Jakarta.Jurnal Akuatika. III (2):169-179.

Zohri L. H. N., Al Idrus A., \& Japa L. (2020). Phytoplankton Diversity as Bioindicator of Pandanduri Dam Waters, East Lombok Regency.Jurnal Biologi Tropis. 20(3): 355-362. 